Génét. Sél. Evol., 1987, 19 (1), 127-132

\title{
Note
}

\section{Segregational patterns of a chromosome insertion in the progeny of twin chimeric bulls}

\author{
J.C.F. MORAES * and Margarete S. MATTEVI ** \\ * Instituto José Ghisolfi, Faculdades Unidas de Bagé, 96400, Bagé, RS, Brazil \\ ** Departamento de Genética, Universidade Federal do Rio Grande do Sul, \\ 90001, Porto Alegre, RS, Brazil
}

\begin{abstract}
Summary
Chromosome studies in 99 offspring of twin bulls, know to be leukocyte chimeras for an insertion in chromosome 16 , revealed that only one sired heterozygotes carrying the abnormal chromosome. This indicated that the chimerism observed in the leukocytes did not extend to the germ cells.
\end{abstract}

Key words: Chimerism, leukocytes, germ cells, ins 16.

\section{Résumé}

Modalités de ségrégation d'une insertion chromosomique dans la descendance de taureaux jumeaux chimériques

L'étude chromosomique de 99 produits de taureaux jumeaux, identifiés comme des chimères leucocytaires pour une insertion dans le chromosome 16 , a montré que seul un taureau a engendré des hétérozygotes portant le chromosome anormal. Ceci montre que le chimérisme observé dans les leucocytes ne s'est pas étendu aux cellules germinales.

Mots clés: Chimérisme, leucocytes, cellules germinales, ins 16.

\section{Introduction}

The insertion in chromosome 16, ins 16 (fig. 1a), probably resulted from a centromeric transposition following 3 breaks in the autosome and was observed in leukocyte cultures from 7 out of a total sample of 81 Charolais cattle. The carriers 
included a pair of chimeric twin bulls (no. II3 and II2) which respectively presented 11 / 30 (37 p. 100) and 11/15 (73 p. 100) of mitotic cells carrying the submetacentric marker chromosome, as against cells with a normal karyotype (MoraEs et al., 1980). Because of the chimeric nature of the twins and the rarity of the insertion in the population, it was concluded that, in terms of lymphomyeloid stem cells, one twin must have originally been heterozygous for the ins 16 whereas the other twin had a normal karyotype and the mixing of cell populations occurred through vascular anastomosis in utero.

Previous studies of the segregational patterns of germ cells in chimeric cattle have largely been concerned with the possibility or otherwise of the survival and function of opposite sex germ cells in the gonads of bulls and freemartin pairs (see for example, FORD \& EVANS, 1977). In many, vascular anastomosis is thought to occur sufficiently early for primordial germ cells in the circulation to pass from one fetus to the gonads of another (Jost \& PrÉPIN, 1966) but, in others, as in the case of the rare fertile freemartins (Eldoridge \& BlazaK, 1977 ; SMith et al., 1977 ; MiYaKe et al., 1980), it may occur too late. The issue cannot be totally resolved in the bulls because of the conflicting reports regarding the ability of $\mathrm{XX}$ germ cells to survive in the testis. In some matings from these bulls, claims have been made that they can survive since an excess of female progeny were born, in others normal sex-ratios were found suggesting no enhancement of X bearing gametes (see for example, FEJÉR \& Kovács, 1980). The latter observation could have resulted from either that the $\mathrm{XX}$ germ cells reached the testis and failed to survive in a foreign environment, or that late vascular anastomosis prevented their migration in the first place. The discovery of the bull twins chimeric for an autosomal marker chromosome, ins 16, provides a means of exploring these 2 possibilities. If the primordial germ cells did migrate from the heterozygous fetus to the normal testis they would expected to survive since they are syngenetic and, more importantly, carry a Y chromosome. The aim of this study was to investigate this possibility by chromosome analysis of the offspring of the chimeric bulls.

\section{Materials and methods}

197 cows were artificially inseminated with frozen semen, 106 from the semen of bull II3 and 91 from that of bull II2. In the resulting offspring 99 animals were karyotyped by the method of MoorHEAD et al. (1960) using leukocyte cultures set up in RPMI 1640 (Flow) with 20 p. 100 fetal calf serum, 4 p. 100 phytohemaglutinin M (Difco), 100 I.U. of penicillin and $100 \mathrm{mg} / \mathrm{ml}$ of streptomycin. The metaphases were conventionally stained in Giemsa and 15 analysed for each animal.

\section{Results and discussion}

The distribution of the karyotype classes observed in the offspring of the 2 bulls are shown in table 1 . In bull II 3,26 out of a total sample of 61 , or 43 p. 100 were heterozygous for ins 16 (fig. 1a), a frequency which is not at variance with the $50 \mathrm{p}$. 
100 expected $\left(\mathrm{X}^{2}=1.05 ; 1\right.$ D.F. ; $\left.\mathrm{P}>0.30\right)$ if the bull was a complete germ line heterozygote and lacked germ cells with a normal karyotype. In contrast, bull II 2 sired 38 offspring all of which were of a normal karyotype (fig. 1b) which suggested that his germ line did not carry the insertion. The difference between the frequency of heterozygous offspring observed for the 2 bulls is highly significant $\left(\mathrm{X}^{2}=22.00 ; 1\right.$ D.F. ; $\mathrm{P}<0.001)$.

TABLE 1

Frequency of normal and abnormal karyotypes in the offspring of the chimeric bulls.

\begin{tabular}{|c|c|c|c|}
\hline \multirow{2}{*}{ Karyotypes } & II 3 & II 2 & Total \\
\hline & p. 100 (no.) & p. 100 (no.) & p. 100 (no.) \\
\hline $60, \mathrm{XX}$ & $34(21)$ & $37(14)$ & $35(35)$ \\
\hline$\ldots \ldots \ldots \ldots \ldots \ldots$ & $21(13)$ & $63(24)$ & $38(37)$ \\
\hline $60, X X$, ins $(16)$ & $23(14)$ & - & $14(14)$ \\
\hline $60, X Y$, ins $(16)$ & $20(12)$ & - & $12(12)$ \\
\hline $59, \mathrm{XX}, \mathrm{t}(1 ; 29)^{*}$ & $2(1)$ & - & $1(1)$ \\
\hline
\end{tabular}

* Anomaly derived from his mother.
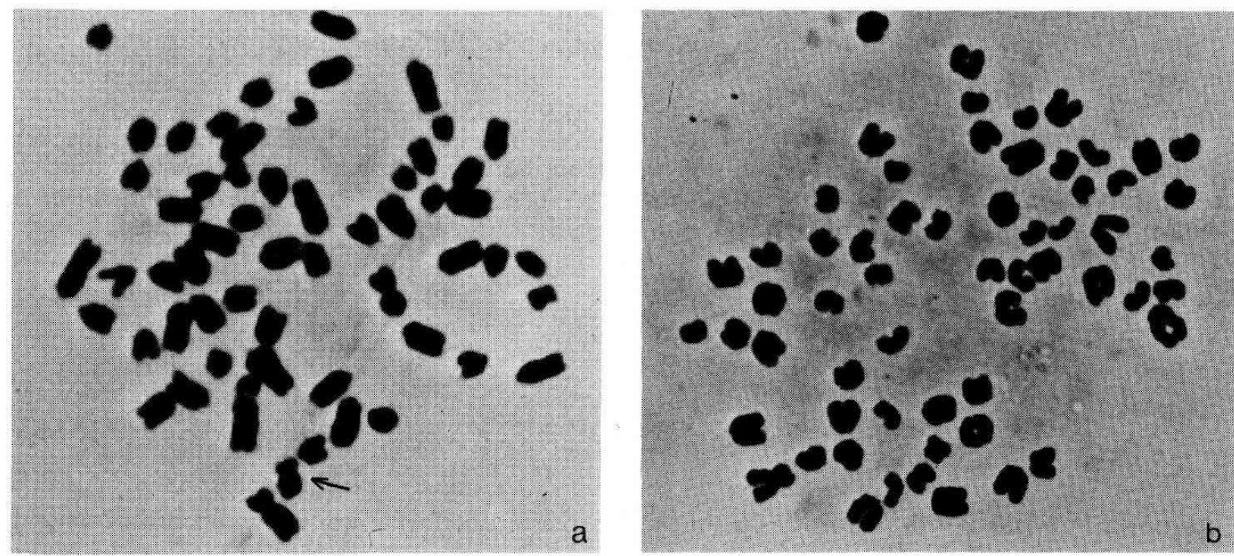

FIG. 1

Metaphases of the two cell lines in the chimeric bulls. a. Heterozygous for the ins(16).

$b$. The normal one. 
Surprisingly, bull II3, although seemingly totally heterozygous in his germ line showed a lower frequency (37 p. 100) of cells carrying ins 16 in his leucocyte culture than did his twin (73 p. 100) with a probable normal germ line. As only one sample of blood was cultured and other tissues were not sampled, it is inappropriate to draw conclusions from this observation.

The results obtained from the leukocyte cultures of the offspring are of interest for the following reason. In contrast to the situation in the testes of bulls born as cotwins to freemartins in which any XX cells are at a disavantage in having both the wrong $\mathrm{X}$ chromosome dosage and being in a potentially hostile XY environment (see FoRD \& Evans, 1977), the normal and heterozygous primordial germ cells in the 2 bulls described here should be of an equivalent proliferative capability because of their equivalent genotypes. Thus, differences in the frequencies of gametes subsequently produced could only result from differences in the initial number of primordial germ cells present during the occupation of the fetal gonad. It has been argued earlier that it is more feasible to consider that the twin zygotes were initially heterozygous and normal and leukocyte chimerism arose later by vascular anastomosis. If this was the case, bull II3, although having the lower leukocyte frequency, is the obvious candidate for the heterozygote and bull II 2 for the normal. The absence of germ cell chimerism in the latter could be explained by vascular anastomosis taking place after the migration of the primordial germ cells to the site of the primitive gonad had finished, a mechanism which has been previously suggested to explain the occurrence of the rare case of fertile freemartins (Eldridge \& BlazAK, 1977 ; SMITH et al., 1977 ; MiYAKE et al., 1980).

Our results support the conclusion that leukocyte chimerism through vascular anastomosis does not necessarily include germ cell chimerism.

Received February 12, 1986.

Accepted September 12, 1986.

\section{Acknowledgements}

We are grateful to Dr. A.K. VAZ for reviewing our manuscript, and we acknowledge the help provided by one anonymous referee who has re-written the paper. This work was supported by the Conselho Nacional de Desenvolvimento Científico e Tecnológico (PIG) and by the Fundação de Amparo à Pesquisa do Estado do Rio Grande do Sul.

\section{References}

Eldridge F.E., Blazak W.F., 1977. Chromosomal analysis of fertile female heterosexual twins in cattle. J. Dairy Sci., 60, 458-463.

Fejêr T., Kovács A., 1980. Offspring sex-ratio of XX/XY chimaerıc bulls. Proc. 4th Eur. Colloq. Cytogenet. Domest. Anim., Uppsala, June 10-13, 1980, 94-98. Department of Animal Breeding and Genetics, Faculty of Veterinary Medicine, Swedish University of Agricultural Sciences, Uppsala. 
Ford C.E., Evans E.P., 1977. Cytogenetic obsérvations on XX/XY chimaeras and a reassessment of the evidence for germ cell chimaerism in heterosexual twin cattle and marmosets. $J$. Reprod. Fert., 49, 25-33.

Jost A., Prépin J., 1966. Données sur la migration des cellules germinales primordiales du fœtus de veau. Arch. Anat. Microsc. Morph. Exp., 55, 161-186.

Miyake Y., Ishikawa T., Abe T., Komatzu M., Kodama Y., 1980. A fertile case of a bovine heterosexual twin female with sex-chromosomal chimerism. Zuchthygiene, 15, 103-106.

Moorhead P.S., Nowell P.C., Mellman W.J., Battips D.M., Hungerford D.A., 1960. Chromosome preparations of leukocyte cultures from human peripheral blood. Exp. Cell Res., 20, 613-616.

Moraes J.C.F., Mattevi M.S., Salzano F.M., Poli J.L.E.H., Erdtmann B., 1980. A cytogenetic survey of five breeds of cattle from Brazil. J. Hered., 71, 146-148.

Smith G.S., Van Camp S.D., Basrur P.K., 1977. A fertile female co-twin to a male calf. Can. Vet. J., 18, 287-289. 